\title{
Financial Performance of Banks in India: Are Banks Sound Enough to be Banked Upon
}

\author{
Sunita Chaki, Dr Kshamta Chauhan, Anita Daryal
}

\begin{abstract}
The seemingly untamable Non-Performing Assets are leading the Indian banks towards a highly unstable environment. The financial soundness of the banks is mandatory for any economy considering it is one of the most significant and a pre-requisite of a stable economy.

The present study examines the financial performance parameters of banks with a probable variation among public and private sector banks for a period between 2005 and 2018.

The study is divided into three sections. The first section studies the financial performance of the Scheduled Commercial Banks (SCBs), Public \& Private Sector Banks in three identified time bands of last thirteen years. The second section assesses the probable variation in asset quality among Private and Public Sector Banks through statistical inferences. The third section finally examines the probability of variations in asset quality in the three time bands identified in the study. The study concludes a very high volatility among the SCBs during the said period and found Private Sector Banks to be more consistent and bore better stability parameters compared to Public Sector Banks. The statistically inferred results through T-test, Welch test and Post-Hoc test support a significant variation among both the sectors along with presence of significant variations in asset quality.
\end{abstract}

Keywords: financial performance, asset quality, profitability, ROA, GNPA, CRAR, capital adequacy, global financial crisis.

\section{INTRODUCTION}

The rising Non-Performing Assets (NPAs) issue of the Indian banks, featuring news on mergers, banks being subjected to Prompt Corrective Action(PCA) and Poor Asset Quality Reviews(AQRs) are indications of a volatile environment in the banks.A study by World Bank[1] have mentionedasset quality of Indian banks in terms of Gross Non-Performing Assets (GNPAs) to be worse than its peer countries in Asia. This wasn't the case prior 2008-09[2]The banks were known to have stable financial parameters with a healthy credit environment. There has been paradigm shift in the status of banks since 2009. The contributing factors being global (global financial crisis), regulatory changes (Basel Norms) as well as domestic (financial and banking reforms) had a strong contagion effect on banking sector. On the global level Basel I,II and III led to a major shift in the risk management, profitability and liquidity condition of Indian Banking Sector.

Revised Manuscript Received on June 15, 2019

Sunita Chaki, Research Scholar, Amity University, Noida.

Dr Kshamta Chauhan, Anita Daryal, Amity University, Amity

University, OBC, Delhi
On the domestic level, the entry of Private Sector Banks (PvBs) led to a competitive environment indicating the banks to be pro-active and pressing requirement of structural transformation in Public Sector Banks (PSBs).

The present study, with this background, tries to assess the financial performance of banks after the financial crisis and following regulatory changes in Basel norms. The financial performance is assessed throughvariables identified inReview of Literature. The data retrieved for the identified variables are from RBI site, Financial Stability Report, Report on Trend and Progress of Banking in India and Annual Reports of the sample banks.

Introduction of economic reforms in 1990s, 2000s and later half of 2010s in the bank has transformed the banking framework in terms of the size, it operations and financial soundness. With the visible imprints of financial crisis (2007-08) spreading across the world, financial sector, including banks, had relatively stable parameters. The economy, however, couldn't remain unaffected from its contagion effect. A report on Trend and Progress of Banking System concludes that even though banks could insulate themselves immediately after the global financial crisis but it couldn't remain immune from its after effect in coming years in terms of slowdown of the economy [3]. This further got reflected in financial performance and soundness of Indian Banking System.

The year 2007-08 had witnessed the first sign of global financial crisis with the sub-prime crisis and loss of confidence of the investors in the US market [2]. A problem started in US, took no time to spread to other countries. India, though managed to protect itself from the initial shock, however the economy soon started showing the signs of domestic slowdown [4]. The banks also indicated it through deteriorated parameters in banking stability [5].

\section{REVIEW OF LITERATURE}

Stability in a banking sector is directly dependent on financial performance, soundness, and liquidityof a bank[6]. Profitability and soundness are the twosubsets of financial performance in the organization [7]. Likewise,asset quality and capital adequacy are known to be two subsets of soundness 
parameters[8]. The existing literature on the study of financial performance (profitability and efficiency)and soundness (asset quality and capital adequacy), researchers have identified certain parameters to measure financial performance and soundness.

Return on Assets (ROA)in this context has been identified as one of the most important parameters of profitability performance [9], [10], [19]-[23], [11]-[18]. ROA indicates the capability of banks to earn profit out of its existing assets[24]. It is calculated by Net Profit (NP)/ Total Assets[23].

Sustainable and improved efficiency leads to economic growth and gives a cushion against the risk attached to the banking business[9]. The efficiency of any organization helps measure the performance in comparison to the industry leader. Net Interest Margin (NIM) is a significant variable in judging the efficiency of a bank[13], [21]-[29]. NIMis taken to be an indicator of intermediation efficiency, where efficiency is measured in terms of deposits deployed to promote income through credit and investments by the bank[23].

Capital Adequacy(CRAR) helps insulate banks from insolvency and provides buffer in case of liquidity crunch[24]. This ratio is an RBI stipulated norm to be adopted by banks. Though the banks are required to maintain a minimum ratio, however, maintaining more than required ratio is an indication of higher degree of soundness of the bank[9], [10], [13], [17], [18], [20], [24].

Maintaining a high CRAR also at times stimulate the risk taking behavior of the banks. A bank taking too much of risk may lead to loan disbursal without much screening and monitoring.

Thus, another criteria which must be looked into for the bank to remain stable on the platform of financial soundness, is it's Asset Quality [30]. Asset quality gained importance especially after 2009-10, when the banks had overly indulged in credit disbursement with poor monitoring mechanism and the over leveraged corporates had started defaulting[30].GNPA, an indicator of asset quality [13], [14], [16], [18], [25]-[27], [31], is measured as the ratio of defaulted loan on advances given [25].

Thus, on the basis of the above review, the study has identified ROA and NIM to be the parameters of financial performance and GNPA ratio and CRAR as indicating parameters of a sound bank.

\section{Methodology}

With an aim to assess the financial performance of the banks in India during the period from 2005 to 2018, the objectives of this paper are as under:-.

1. To assess the profitability, efficiency, capital adequacy \& asset quality of scheduled commercial banks.

2. To compare the financial performance parameters \& examine the statistical variations among private \& public sector banks.

3. To identify the variation among banks on the basis of the three identified phases identified in the study.

Accordingly the hypotheses framed and tested are as under:-

$\mathrm{H}_{\mathrm{A}} 1$ : Financial stability of private sector banks is better compared to public sector banks.

$\mathrm{H}_{\mathrm{O}}$ 2: There is no significant difference between the Mean scores of asset quality in the Public and Private Sector Banks.

$\mathrm{H}_{\mathrm{O}} 3$ : There is no significant difference between the mean scores of asset quality in the three time bands.

The sample banks under study include forty Public and Private Sector Banks. The assessment period has been taken to be from 2005 to 2018 . Taking cues from literature and the evident changes in pre and post global financial crisis, the study has been divided into three phases with different time bands. The First Phase(200405 to 2007-08)is prior to the global financial crisis. The Second Phase is that of post-global crisis (2008-09 to 2014-15). Theperiod starting from 2014-15 iscategorized as third phase(2014-15 to 2018-19) is the period during which reforms were introduced by the regulators.

After evaluating the status of all Scheduled Commercial Banks (SCBs), a comparative analysis between public and private banks from 2005 to 2018 has been done through T-test.

The study further assesses the variation of asset quality on the basis of three time band category. Statistically the analysis was done throughone way ANOVA to check the significant difference in the mean scores of continuous variable.Applying Post-hoc test, the study also identifies where the most variation lies.

\section{RESUltS AND DISCUSSIONS}

\section{Section 1:Financial Performance of Banks.}

Prior to the time when the financial crisis could be evidently seen, the overall financial performance of the banking sector has been evidently stable. By thetime global financial crisis got spread across the world, Indian economy started showing the signs of economic slowdown[3]. During this phase, with the entry of new private sector banks, public sector banks faced the challenges of competitive environment. The stability and financial performance of the banksreached rock bottom by 2014-15. Rising to the grim environment, RBI in 2015-16[32] introduced massive corrective measures in the form of revised regulatory frameworks, initiation of Corporate Debt Restructuring, Scheme for Sustainable Structuring of Stressed Assets, 5/25 Scheme and diligent efforts on behalf of the regulators and banks to enhance the accountability and transparency through Asset Quality Review[2]. This was in addition to government initiated effort of 
recapitalization of PSBs and Indradhanush (banking related reforms). This period also witnessed impact of Insolvency and Bankruptcy Code 2016 -new recovery tool given to manage asset quality of the banks. The banks, post 2016, had almost done with the NPAs provisioning and were able to contain the steep fall in financial and soundness parameters. The detailed analysis is as given below:-

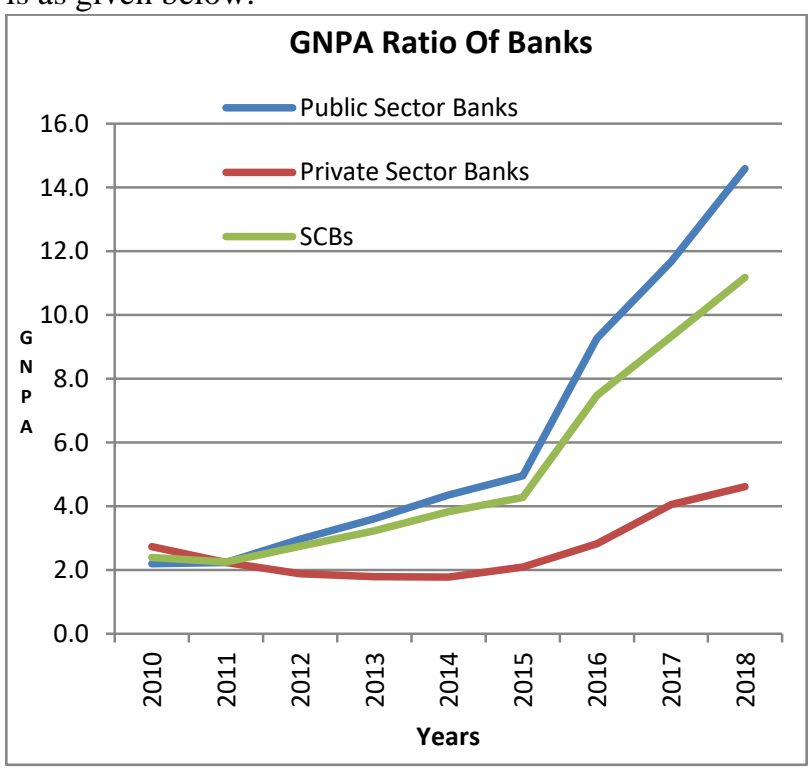

Figure 1 : GNPA Ratios of Banks

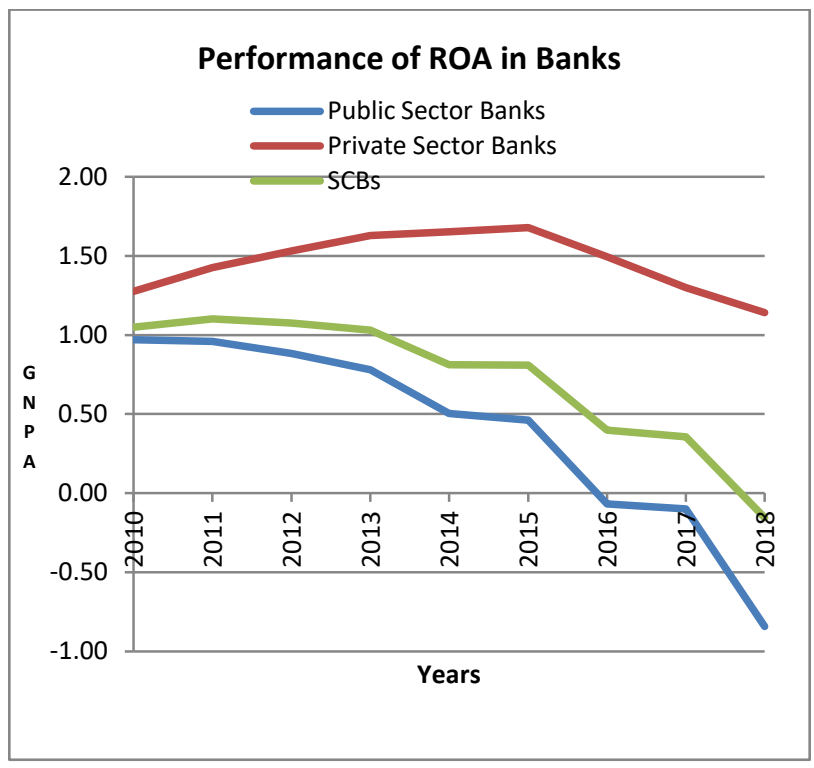

Figure 2 : Performance of ROA in Banks

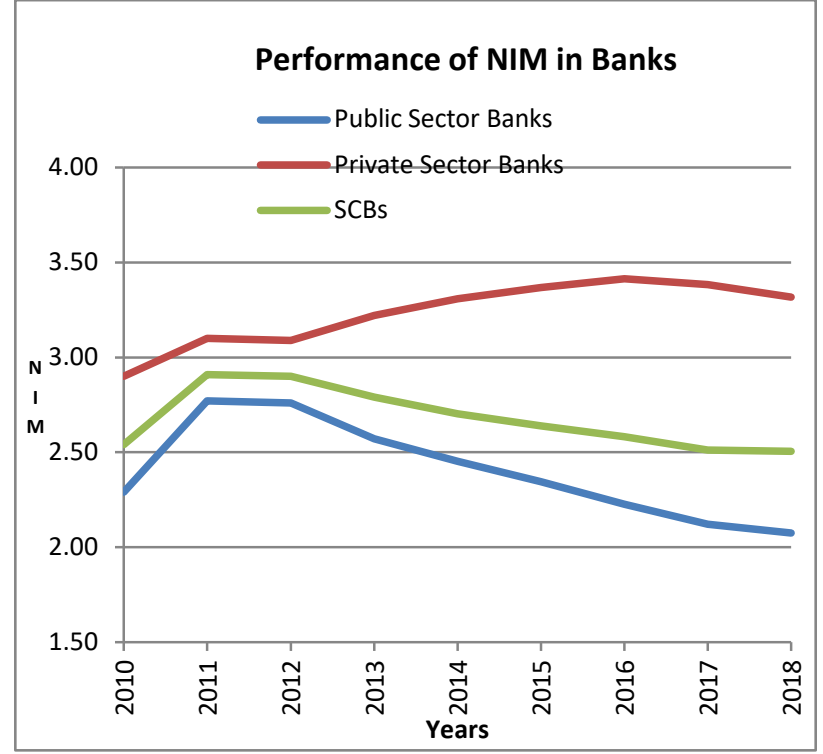

Figure 3 : Performance of NIM in Banks

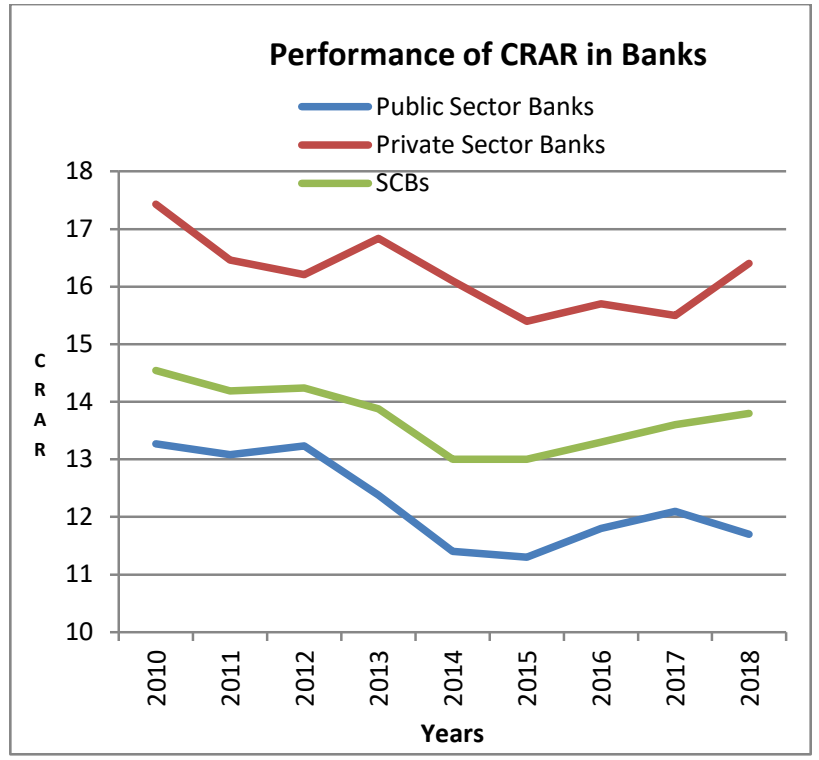

Figure 4 : Performance of CRAR in Banks

$2005-2008$

Having a strong macroeconomic environment,20052008 witnessed a congenial industrial climate, a sharp increase in credit growth, low-fresh accruals in NPA and significant recovery in NPAs.2006-07 indicated an increase in interest rate due to high credit demand the status of financial performance and asset quality still remained robust[6], [33].Likewise 2007-08 showed some sign of stress with the entry of PvBs leading to a competitive environment[34].This year saw a mild slide in profitability,efficiency and asset quality indicators; the overall performance however was comfortably stable.Net profit for instance remained high except with the difference that the reason was credited to non-interest income and banks were able to keep

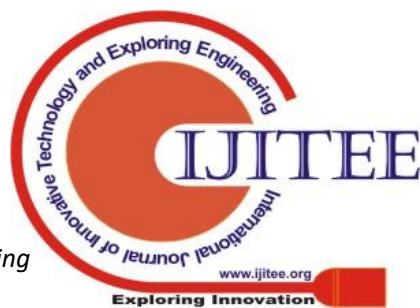


the operating expenses low.The stressed assets showed a sign of trending GNPA in absolute terms still GNPA ratio came down from $2.5 \%$ to $2.3 \%$. The CRAR registered an increase and keeping high provisioning than the required rate, the banks by now were totally unaffected with the global financial crisis evidently prevailing in US.

The asset quality in the year2008-09 (with recovery reported to be as much as 38,828 crores than 28,823 crores in 2007-08) was betterthan in past couple of years. The PvBs, this year, registered to have done more provisioning than Public sector banks. The Public Sector though wasstill in as sound a position as expected by any developing economy. This phase thus was marked by a stable banking environment attributed to profitability,efficiency capital adequacy and asset quality.

\section{9 - 2014}

By 2008-09,banking system showing the sign of mild stress, the initial years of this phase were a mix of subtle highs and lows.Due to high credit disbursement in the previous years, the GNPA in 2008-09 to 2010-11 had started rising in an absolute terms. The provisioning followed the same suit.The net profit during 2009 was recorded to slip from $36.9 \%$ to $23.5 \%$ [7]. The provisions also rose to a huge $43 \%$ from a relatively small $23.5 \%$. Due to high provisioning, the banks still could manage to arrest further rise in GNPA ratio. This phase also saw the recovery to be less than fresh accretions which was contrary to years mentioned in first phase.

The private sector, contrary to public sector banks, seemed to be pro-active with higher provisioning. Even the SCBs could manage to improve GNPA ratio from 2.39 in $2009-10$ to 2.25 in 2010-11 [35], [36]. To manage the recovery, the banks started adopting write-offs as a means to shed the stressed assets.On the same lines, recovery registered was as much as one third of total amount claimed for recovery. The year 2011-12 got hit by escalating interest rates. This year also indicated a sharp increase in GNPA ratio. The situation among PSBs was found to be more concerning then PvBs. This was most evident in GNPA ratio and provisioning done against stressed assets. The year 2012-13 indicated escalation of stress in the form of declining ROA, credit growth and a moderated CRAR[8]. This year also highlighted the growing difference in the performance of public and private sector banks with private sector mitigating GNPA by additional provisioning and arresting the fall by reducing the operating expenses.

\section{5 - 2018}

By 2013-14 the public sector banks were fully entangled with asset quality problem. This though was evident in private sector as well; however the severity was significantly low.The year 2013-14, 14-15 and 2015-16 were on the similar pattern except the gravity of the sliding financial performance and soundness parameters were getting worse[32], [37], [38].
The RBI by now was active in coming up with several remedial and corrective measures related to capital provisioning revitalising the banks stressed assets and arming the banks with more robust recovery channels. The measures however were yet to deliver results. The banks especially PSBs, by 2015-16, were beleaguered with poor asset quality, dented profitability and restricted credit growth.The RBI had concluded Asset Quality Review (AQR), which made the bank do more provisioning with greater transparency. By 2017-18, banks were seen to be in relatively steadier position. Asset Quality in terms of GNPA improved in the sense that the rate of downward trending experienced by banks was somewhat arrested in 2017-18.

\section{Section 2: Asset Quality in Private and Public Sector Banks}

Assessing the graphical trends of the stability of banking sector, the studyfurtherattempts to examine a comparative difference among Public and Private Sector Banks. It has theoretically been established in the study that the PvBs historicallyhave been proactive while PSBs always are observed to have a lagged period to react and act to the demanding environment. To assess the probable difference among the two categories, an independent sample T-test was applied to compare asset quality in PSBs and PvBs in India. The criteria of Normal Distribution and Levene Test of homogeneity were conducted wherein the parameter was log transformed. Levene test also indicated the equality of variance to be highly significant.

Group Statistics

\begin{tabular}{|l|l|l|l|l|l|}
\hline & ownership & $\mathrm{N}$ & Mean & $\begin{array}{l}\text { Std. } \\
\text { Deviation }\end{array}$ & $\begin{array}{l}\text { Std. Error } \\
\text { Mean }\end{array}$ \\
\hline $\begin{array}{l}\text { Log_GN } \\
\text { PA }\end{array}$ & $\begin{array}{l}\text { Public Sector } \\
\text { Banks }\end{array}$ & 260 & .5510 & .30155 & .01870 \\
& $\begin{array}{l}\text { Private Sector } \\
\text { banks }\end{array}$ & 208 & .3893 & .27528 & .01909 \\
\hline
\end{tabular}

Figure 5 : Descriptive Statistics 
Independent Samples Test

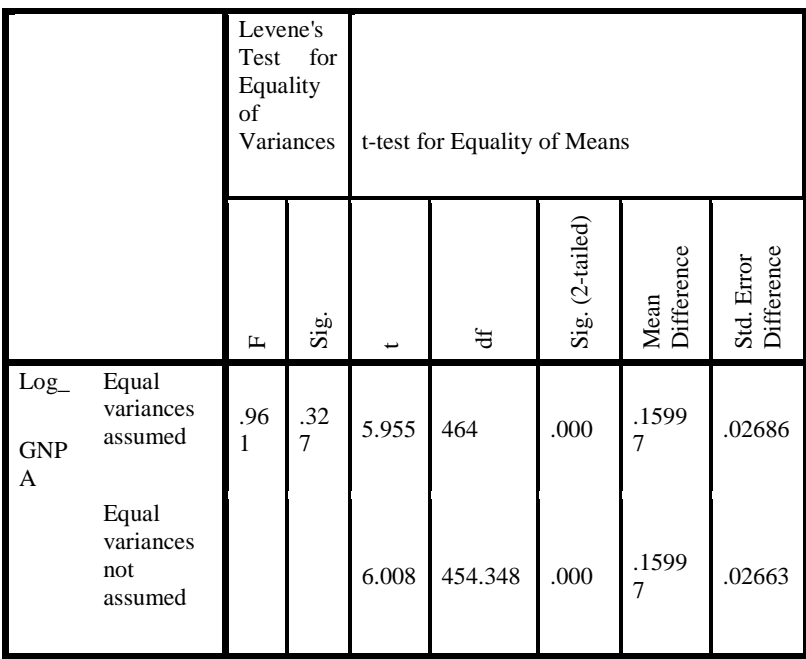

Figure 6 : Independent Samples T-Test

T-test indicated a significant difference existing between PSBs (Mean=.5510, $\mathrm{SD}=.30155)$ and PvBs (Mean=.3893, $\mathrm{SD}=.27528$ ). The $\mathrm{t}$-value analysed was $\mathrm{t}(464)=5.955 \& \mathrm{p}$-value $=000$.

\section{Section 3 : Asset Quality in the Three Time Bands}

To corroborate the theoretical indications, the variation among the three time bands on the basis of asset quality parameter was also performed. Asset quality was taken to be dependent variable while time band(s), categorical variable, was taken to be independent variable. The assumption of normality and homogeneity of variance was conducted using Kolmogorov-Smirnova (KS) Shapiro-Wilk andLevene test respectively.

\begin{tabular}{|c|c|c|c|c|c|c|c|}
\hline \multicolumn{8}{|c|}{ Tests of Normality } \\
\hline & \multirow{2}{*}{ Phase } & \multicolumn{3}{|c|}{ Kolmogorov-Smirnova } & \multicolumn{3}{|c|}{ Shapiro-Wilk } \\
\hline & & Statistic & df & Sig. & Statistic & df & Sig. \\
\hline \multirow{3}{*}{$\log \_$GNPA } & 1 & .039 & 144 & $.200 *$ & .996 & 144 & .940 \\
\hline & 2 & .056 & 180 & $.200 *$ & .990 & 180 & .216 \\
\hline & 3 & .057 & 144 & $.200 *$ & .983 & 144 & .066 \\
\hline
\end{tabular}

*. This is a lower bound of the true significance.

Lilliefors Significance Correction

Figure 7 : Test of Normality

\begin{tabular}{|l|l|l|l|}
\hline \multicolumn{5}{|l|}{ Test of Homogeneity of Variances } \\
\hline log_GNPA & df1 & df2 & Sig. \\
\hline Levene Statistic & 2 & 465 & .000 \\
\hline 22.040 & & & \\
\hline
\end{tabular}

Figure 8 : Test of Homogeneity of Variances

\begin{tabular}{|c|c|c|c|c|}
\hline \multicolumn{5}{|c|}{ Robust Tests of Equality of Means } \\
\hline \multicolumn{5}{|c|}{$\log \_$GNPA } \\
\hline & Statistic ${ }^{\mathrm{a}}$ & df1 & df 2 & Sig. \\
\hline Welch & 48.629 & 2 & 281.758 & .000 \\
\hline
\end{tabular}

Figure 9 : Robust Tests of Equality of Means

\begin{tabular}{|c|c|c|c|c|c|c|}
\hline \multicolumn{7}{|c|}{ Multiple Comparisons } \\
\hline \multicolumn{7}{|c|}{ Dependent Variable: log_GNPA } \\
\hline \multicolumn{7}{|c|}{ Games-Howell } \\
\hline \multirow[b]{2}{*}{$\begin{array}{l}\text { (I) } \\
\text { Phase }\end{array}$} & \multirow[b]{2}{*}{$\begin{array}{l}\text { (J) } \\
\text { Phase }\end{array}$} & \multirow[b]{2}{*}{$\begin{array}{l}\text { Mean } \\
\text { Difference } \\
(\mathrm{I}-\mathrm{J})\end{array}$} & \multirow[b]{2}{*}{$\begin{array}{l}\text { Std. } \\
\text { Error }\end{array}$} & \multirow[b]{2}{*}{ Sig. } & $\begin{array}{l}95 \% \\
\text { Interval }\end{array}$ & Confidence \\
\hline & & & & & $\begin{array}{l}\text { Lower } \\
\text { Bound }\end{array}$ & $\begin{array}{l}\text { Upper } \\
\text { Bound }\end{array}$ \\
\hline \multirow[t]{2}{*}{1} & 2 & $.15891^{*}$ & .02625 & .000 & .0971 & .2208 \\
\hline & 3 & $-.14873^{*}$ & .03571 & .000 & -.2329 & -.0645 \\
\hline \multirow[t]{2}{*}{2} & 1 & $-.15891^{*}$ & .02625 & .000 & -.2208 & -.0971 \\
\hline & 3 & $-.30764^{*}$ & .03326 & .000 & -.3861 & -.2292 \\
\hline \multirow[t]{2}{*}{3} & 1 & $.14873^{*}$ & .03571 & .000 & .0645 & .2329 \\
\hline & 2 & $.30764^{*}$ & .03326 & .000 & .2292 & .3861 \\
\hline
\end{tabular}

\section{Figure 10 : Post-Hoc Test}

The GNPA, an indicator of asset quality, after log transformation, became normally distributed. While conducting Levene test, null hypothesis of test on homogeneity got rejected indicating the variation between the three groups to be not equal to zero. This ledthe study towards Welch test. Welch test $\mathrm{F}(2,281.75)$ $=48.62$, Pvalue=.000 indicated a significantly high variation among the mean scores of the three time bands. Post-hoc test was applied to compare the time bands in three paired groups which indicated significant amount of variations in mean scores of the three time bands.

Interpretation. In the pre financial crisis phase, the SCBs in India had a positive and congenial credit climate with ROA,NIM,GNPAs and well addressed capital adequacy. However, performance of post financial crisis phase, the banks started 
indicating an unwarranted stress. The stress dented the profitability and asset quality parameters the most.

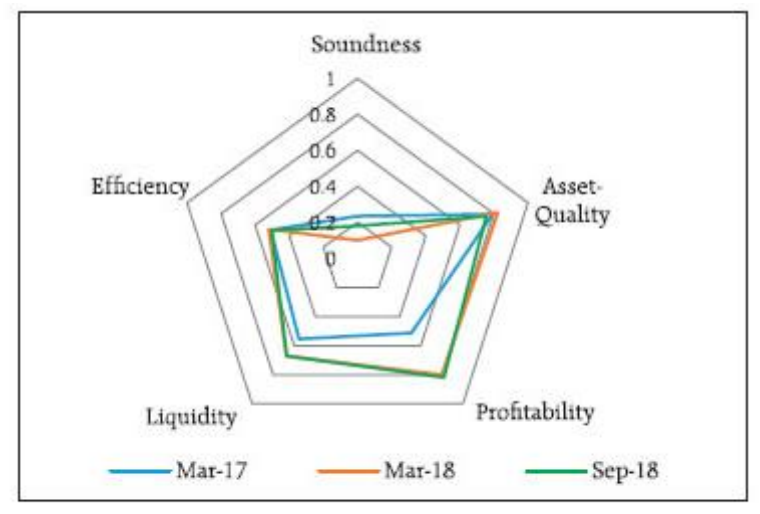

Noter Away from the centre signifies increase in risk. Source; RBI supervisorv returns and staff calculations.

\section{Figure 11 : Banking Stability Map (Source - RBI Trends and Progress 2017-18)}

This stress seemed to be gravitated more towards the PSBs compared to their counterparts. This was mainly because of private banks were proactive maintaining the asset quality by either provisioning against rising GNPAs or using the write-off channel to deal with the problem. This, however, was not the case with PSBs. Even after infusion of capital, they were more into remedial measures than being proactive. This is the reason why when all the banks were registering deterioration in their financial performance private sector banks registered much less impact and were able to bounce back in much less time in terms of net profit much faster compared to PSBs.

Recommendations. There have been number of times when the volatility in banking sector has been attributed to the external forces which were beyond control of the Banking Sector. For banks to survive in such like testing times, they need to be proactiveto minimise the damage. Beside this, the banks internally need to strengthen themselves by being more competitive along with a high degree of transparency and accountability. These are the areas PSBs have categorically been laggingin. The relatively betterperformance of PvBs vis-à-vis PSBs, this proposition doesn't seem to be an impossibletask. Also, it is necessary for the regulators to identify the weak banks from strong PSBs. Weak banks may be liquidated or be merged with the stronger banks to derive the advantages of economies of scales.

\section{Conclusion}

From the time the global financial crisis started showing its contagion effect on the Indian economy, the financial performance and soundness indicators witnessed a chequered performance. In the past ten years, the banking sector has been exposed to external and internal volatility. Even though the PvBs underwent the same stresses of the global downturn, interest rate volatility and introduction of new regulatory frameworks, yet they were seen to be more cautious, proactive and resilient in managing the turbulent environment and thus could bounce back in a more fastidious manner.

PSBs, on the other hand, have been observed to have a lagged reaction time of such volatilities and thus have been seen to have taken more reaction time than its counterpart.

Looking at the overall stability graph of Scheduled Commercial Banks provided in Trend and Progress in 2018, it is easy to comprehend that the banks have had difficult times on account of maintaining asset quality and profitability. However they have been able tomanagethe efficiency and capital adequacy parameters in relative terms.

With the initiation of asset quality reviews, policydriven provisioning regulatory framework, recapitalization move by the central government, mergers of public sector banks and end of forbearance of RBI towards banks, the position of public sector banks in terms of profitability, efficiency, capital adequacy, and asset quality may be expected to be on a sound platform.

\section{REFERENCES}

[1] W. Bank, "Doing Business-India 2019," 2019.

[2] Assocham and E\&Y, "ARCs - at the crossroads of making a paradigm shift," 2016

[3] Reserve Bank of India, "Report on Trend and Progress of Banking in India 2012-13," 2013.

[4] S. Mundra, "Financial Stability in a Weak Global Environment," in Financial Stability in a Weakening Global Economic Environment, 2016, p. 2016.

[5] Reserve Bank of India, "Financial Stability Report 2013-14," 2013.

[6] Reserve Bank of India, "Report on Trend and Progress of Banking in India 2005-06," 2006.

[7] Reserve Bank of India, "Report on Trend and Progress of Banking in India 2008-09," 2009.

[8] Reserve Bank of India, "Report on Trend and Progress of Banking in India 2014-15,” 2014

[9] A. Derviz and J. Podpiera, "Predicting Bank CAMELS and S \& P Ratings The Case of the Czech Republic," vol. 44, no. 1, pp. 117130, 2008.

[10] K. B. L. Mathur, "Should They be privatised," Econ. Polit. Wkly., vol. 37, no. 23, pp. 2245-2256, 2012.

[11] M. Sathye, "Privatization, Performance, and Efficiency: A Study of Indian Banks," vol. 30, no. 1, pp. 7-16, 2005.

[12] J. B. Thomson, "Predicting Bank Failures in the 1980s," no. 1988, 1990.

[13] S. Kumar and R. Sharma, "Performance Analysis Of Top Indian Banks Through Camel," Int. J. Adv. Res. Manag. Soc. Sci., vol. 3 , no. 7, pp. 81-92, 2014.

[14] C. S. Balasubramanium, "Non Performing Assets and Profitability of Commercial Banks in India:Assessment and Emerging Issues," Abhinav,Journal Res. Commer. Manag., vol. 1, no. 7, pp. 41-52, 2012.

[15] F. N. Echekoba, C. F. Egbunike, and E. G. Kasie, "Determinants of Bank Profitability in Nigeria: Using Camel Rating Model," no. January, 2014

[16] A. Roman and A. Camelia, "Analysing the Financial Soundness of the Commercial Banks in Romania: An Approach Based on the Camels Framework," Procedia Econ. Financ., vol. 6, no. 13, pp. 703-712, 2013.

[17] N. Rozzani and R. A. Rahman, "Camels and Performance Evaluation of Banks in Malaysia: Conventional Camels and Performance Evaluation of Banks in Malaysia: Conventional Versus Islamic," no. July 2014, 2013. 
[18] A. B. Review, "A Study on Testing the Operating Efficiency of Indian Banking Sector with Special Reference to the Select Financial Soundness Indicators - An Empirical Approach," vol. VII, no. 3, pp. 72-83, 2011.

[19] H. V. Kaur, "Analysis of Banks in India - A CAMEL Approach," vol. 2, pp. 257-280, 2010.

[20] M. Evans, "An Indonesian Study of the Use of CAMEL ( S ) Ratios as Predictors of Bank Failure An Indonesian Study of the Use of CAMEL ( S ) Ratios as Predictors of," vol. 10, no. 1, 2005.

[21] M. Ibrahim, "A Comparative Performance of Two Banks in United Arab Emirates," vol. 5, no. 21, pp. 24-30, 2014.

[22] W. K. Wang, W. M. Lu, and Y. H. Wang, "The relationship between bank performance and intellectual capital in East Asia," Qual. Quant., vol. 47, no. 2, pp. 1041-1062, 2013.

[23] I. Keramidou, A. Mimis, and A. Fotinopoulou, "Exploring the relationship between efficiency and profitability," vol. 20, no. 5, pp. 647-660, 2013.

[24] S. Banerjee and M. Velamuri, "The Conundrum of Profitability Versus Soundness NU Abstract," Rev. Financ. Econ., 2015.

[25] S. Kumar and R. Gulati, "Measuring efficiency, effectiveness and performance of Indian public sector banks," 2010.

[26] D. Gasbarro, "The Changing Relationship Between CAMEL Ratings and Bank Soundness during the Indonesian Banking Crisis," pp. 247-260, 2002.

[27] M. Mercan, A. Reisman, R. Yolalan, and A. B. Emel, "The effect of scale and mode of ownership on the financial performance of the Turkish banking sector: Results of a DEA-based analysis," Socioecon. Plann. Sci., vol. 37, no. 3, pp. 185-202, 2003.

[28] P. Singh, "Efficiency Assessment Parameters of Public Sector Banks in India," 2015.

[29] P. Manoj, "Financial Soundness of Old Private Sector Banks In India With a Focus on Kerala Based OPBs: A 'CAMEL' Approach,” Am. J. Sci. Res., no. 11, pp. 132-149, 2010.

[30] A. Quality, "Asset Quality of Indian Banks : Way Forward 1," 2016.

[31] S. S. Shukla, "Analysing Financial Strength of Public and Private Sector Banks : A CAMEL Approach,” vol. 7, no. 8, 2015.

[32] Reserve Bank of India, "Report on Trend and Progress of Banking in India 2016-17," 2017.

[33] Reserve Bank of India, "Report on Trend and Progress of Banking in India 2004-05," 2005.

[34] Reserve Bank of India, "Report on Trend and Progress of Banking in India 2007-08," 2008.

[35] Reserve Bank of India, "Report on Trend and Progress of Banking in India2009-10,” 2010.

[36] Reserve Bank of India, "Report on Trend and Progress of Banking in India 2010-11," 2011.

[37] Reserve Bank of India, "Report on Trend and Progress of Banking in India 2015-16," 2015.

[38] Reserve Bank of India, "Report on Trend and Progress of Banking in India 2017-18," 2018.

\section{AUTHORS' PROFILE}

Ms. Sunita Chaki, Ph.D Scholar at Amity University, Noida. She has also published papers on 'Indian Banking - Challenges, Reforms and Road Ahead' in the International Journal of Banking, Risk and Insurance and 'On the Roads to Recovery : How Far to Go?' in Indian Journal of Economics and Business

Dr. Kshamta Chauhan, an Associate Professor in Amity University Noida, has a teaching experience of over 19 years. She specializes in International Business, Economics and Banking.

Ms. Anita Daryal is a Chief Manager- Law, presently posted in Oriental Bank of Commerce, Delhi. She has an experience of 25 years in the recovery and law department of the Bank. 